A N N A LE S

UNIVERSITATIS MARIAE C URIE-SKŁODOW K A LUBLIN - POLONIA

VOL. LXXII, z. 1

SECTIO B

2017

Wydział Turystyki i Rekreacji, Zakład Ekologii

Akademia Wychowania Fizycznego im. Bronisława Czecha w Krakowie

31-571 Kraków, al. Jana Pawła II 78

katarzyna.gmyrek@awf.krakow.pl

KATARZYNA GMYREK-GOŁĄB

\title{
Warunki rozwoju turystyki w Eggenburgu
}

Conditions of tourism development in Eggenburg

Słowa kluczowe: Dolna Austria, Waldviertel, Eggenburg, region turystyczny, produkt turystyczny

Keywords: the Lower Austria, Waldviertel, Eggenburg, tourist area/region, tourist product

\section{WPROWADZENIE}

Postrzeganie atrakcyjności turystycznej danego terenu w dużej mierze uzależnione jest od możliwości przystosowania go do uprawiania różnych form turystyki. Turystyka jest zjawiskiem bardzo dynamicznym i czułym na zmiany, dlatego w jej planowaniu niezbędna jest obserwacja zachodzących przemian społeczno-ekonomicznych oraz przekształceń środowiska przyrodniczego, jak również zmieniających się potrzeb turystów i konieczności zapewnienia im interesujących produktów (Gmyrek-Gołąb, Łabaj 2005).

O przydatności przestrzeni dla ruchu turystycznego decyduje wiele kryteriów, zarówno ze sfery walorów turystycznych, jak i infrastruktury. Pojęcie regionu nie zostało jednoznacznie zdefiniowane. Problematyka dotycząca regionu rozpatrywana jest z punktu widzenia różnych nauk. Przypisuje się im rozmaite cechy (Kowalczyk, Derek 2010) i stosuje się również różne metody badań (Kruczek, Zmyślony 2010). Region turystyczny definiuje się jako terytorium z pewną charakterystyczną kombinacją cech przyrodniczych i społeczno-ekonomicznych. Kiedyś ujmowany był jedynie na płaszczyźnie geograficznej jako obszar o pewnej jednorodności cech środowiska oraz wewnętrznych powiązań usługowych. Obecnie rozpatruje się go również z punktu widzenia marketingowego, odnosząc jego 
kreacje do roli produktu turystycznego miejsca. Z kolei dla ekonomistów region jest narzędziem działania służącym tworzeniu systemu organizacji przestrzennej, która obejmuje skład, strukturę i otoczenie (Kruczek, Zmyślony 2010).

Pojęcie regionu turystycznego na pewno należy rozpatrywać kompleksowo, biorąc pod uwagę zarówno atrakcyjność walorów turystycznych, poziom zagospodarowania turystycznego, koncentrację ruchu turystycznego oraz wewnętrzne powiązania i spójność (Liszewski 2003). Zagadnienie regionu turystycznego związane jest z działalnością turystyczną, czyli zjawiskiem przestrzennym, ekonomicznym i społecznym.

Celem opracowania jest pokazanie, w jaki sposób niewielkie miejscowości, takie jak Eggenburg położony w Dolnej Austrii, mogą osiągnąć sukces na rynku turystycznym i kreować swoje regionalne produkty turystyczne dzięki wyraźnie określonym celom strategicznym.

Przedstawione w pracy badania zostały oparte na dostępnych danych z roczników statystycznych z roku 2016 oraz danych uzyskanych z Urzędu Miasta Eggenburg. W pracy wykorzystano również informacje zawarte $\mathrm{w}$ strategiach rozwoju, m.in. Strategii Rozwoju Turystyki Dolnej Austrii do roku 2020.

\section{DOLNA AUSTRIA JAKO REGION TURYSTYCZNY}

Austria leży w środkowej Europie - brak dostępu do morza sprawia, że jest krajem śródlądowym, $62 \%$ powierzchni kraju stanowią Alpy, stąd też często nazywa się ją państwem alpejskim.

Austria jest republiką i dzieli się na dziewięć krajów związkowych (landów): Voralberg, Tyrol (Tirol i Osttirol), Salzburg, Karyntia (Kärtner), Dolną Austrię (Niederösterreich), Górną Austrię (Oberösterreich), Burgenland i Wiedeń (Wien), który jako stolica państwa stanowi też odrębny kraj związkowy (ryc. 1).

Największym powierzchniowo krajem związkowym jest Dolna Austria (Niederösterreich) - 19,2 tys. $\mathrm{km}^{2}$ (co stanowi 23\% powierzchni całej Austrii), a zamieszkuje ją 1,6 mln mieszkańców (19\% całej populacji kraju) (www.statistik. at/web_de/statistiken/index.html 2016); jego stolicą od 1986 roku jest St. Pölten (dawniej był nią Wiedeń). Ten kraj związkowy, okalający stolicę kraju - Wiedeń, łączy w sobie kulturę i tradycję. Z historycznego punktu widzenia Dolna Austria nie bez znaczenia nazywana jest „kolebką państwa”, tutaj bowiem przed 1000 lat zapisano po raz pierwszy nazwę Austrii, brzmiącą wtedy „Ostarrichi” (Ost niem. wschód i Reich - niem. bogactwo).

Dolna Austria z punktu widzenia atrakcyjności turystycznej jest krainą wielu kontrastów, wynikających zarówno z uwarunkowań przyrodniczo-geograficznych, jak i kulturowych (Gmyrek 2004). Leży ona po obu brzegach Dunaju i obok Burgenlandu jest zróżnicowaną pod względem fizyczno-geograficznym krainą, 

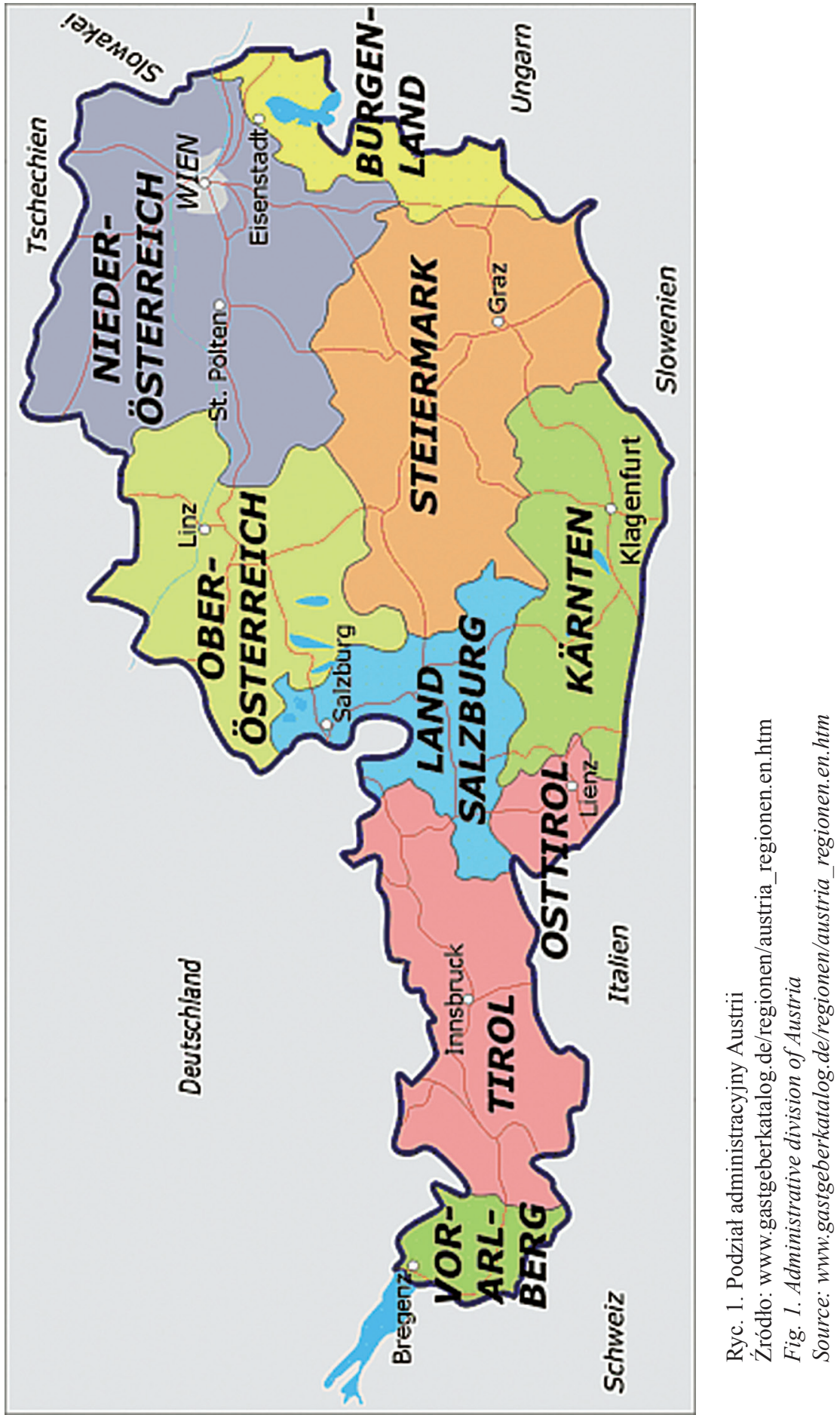
ale z dużym udziałem krajobrazów równinnych (średnia wysokość 200-400 m n.p.m.). Na północy wznosi się lesista część Masywu Czeskiego, wschód przynależy już do południowego Przedgórza Karpackiego. W granice części południowej landu wchodzi pagórkowaty obszar Przedgórza Alpejskiego, wzgórza Lasu Wiedeńskiego, wysokogórski krajobraz Alp Austriackich, z najwyższymi szczytami Rax Alpe (2007 m n.p.m.) i Schneeberg (2076 m n.p.m.) oraz kontrastująca z nim rozległa zapadliskowa Kotlina Wiedeńska. Na linii uskoku Alpy - Kotlina Wiedeńska występuje wiele źródeł wód mineralnych i termalnych, które znane już były w czasach starożytnych. Główną rzeką jest Dunaj. Dolina Dunaju stanowi ważny element krajobrazowy i komunikacyjny, zwłaszcza przełom Doliny Wachau (między Melk, a Krems) oraz przełom przez Las Wiedeński.

Dolina Dunaju Dolnej Austrii niewątpliwie przedstawia najstarszy krajobraz kulturowy Austrii i od roku 2000 posiada status Światowego Dziedzictwa UNESCO. Znajduje się tu około 50 zamków i 600 muzeów. Obiekty o dużej wartości kulturowej skupione są głównie wzdłuż Dunaju, jak na przykład trzy duże opactwa: Melk, Göttweig i Klosterneuburg, w których zgromadzono liczne zbiory dzieł sztuki i literatury o dużej wartości historycznej. W regionie organizowane są wydarzenia i festiwale kulturalne, wiele z nich o zasięgu międzynarodowym, przykładowo: Festiwal Teatrów Ulicznych w Melku, Międzynarodowy Festiwal Folklorystyczny w Krems, Przegląd Sztuki Dunaju w Baden (Gmyrek 2004).

Na terenie Dolnej Austrii dużą wagę przywiązuje się do ochrony przyrody, czego efektem jest promocja i popularność proekologicznej, zrównoważonej turystyki przyjaznej środowisku (Tourismusstrategie Niederösterreich 2020).

W roku 1995 Dolna Austria była podzielona na siedem regionów turystycznych, a obecnie jest ich sześć, z których każdy reprezentuje odmienny i unikatowy charakter. Są to regiony: Waldviertel, Weinviertel, Mostviertel, Las Wiedeński (Wienerwald), Alpy Wiedeńskie (Wiener Alpen), oraz Dolina Dunaju Dolnej Austrii (Donau-Niederösterreich) (ryc. 2).

Dzięki zróżnicowanym walorom przyrodniczym i kulturowym, w Dolnej Austrii można uprawiać różne formy turystyki, począwszy od turystyki poznawczej, w tym kulturowej, poprzez zdrowotną i leczniczą, a skończywszy na różnych formach turystyki kwalifikowanej - narciarskiej, wodnej, konnej czy rowerowej.

Opierając się na zróżnicowanym potencjale i równocześnie mając na uwadze indywidualny charakter poszczególnych regionów turystycznych, stworzono w Dolnej Austrii, w roku 2014, uniwersalną strategię rozwoju turystyki do roku 2020 (Tourismusstrategie Niederösterreich 2020). W tym dokumencie podkreślono walory danego regionu oraz miejscowości leżących w jego obrębie, które mogłyby stanowić jego atut, mocną stronę. Ponadto zwracano uwagę na spójną wizję rozwoju całego kraju związkowego. Za pomocą analizy SWOT określono mocne i słabe strony oraz szanse i zagrożenia rozwoju turystyki w Dolnej Austrii (tab. 1). 


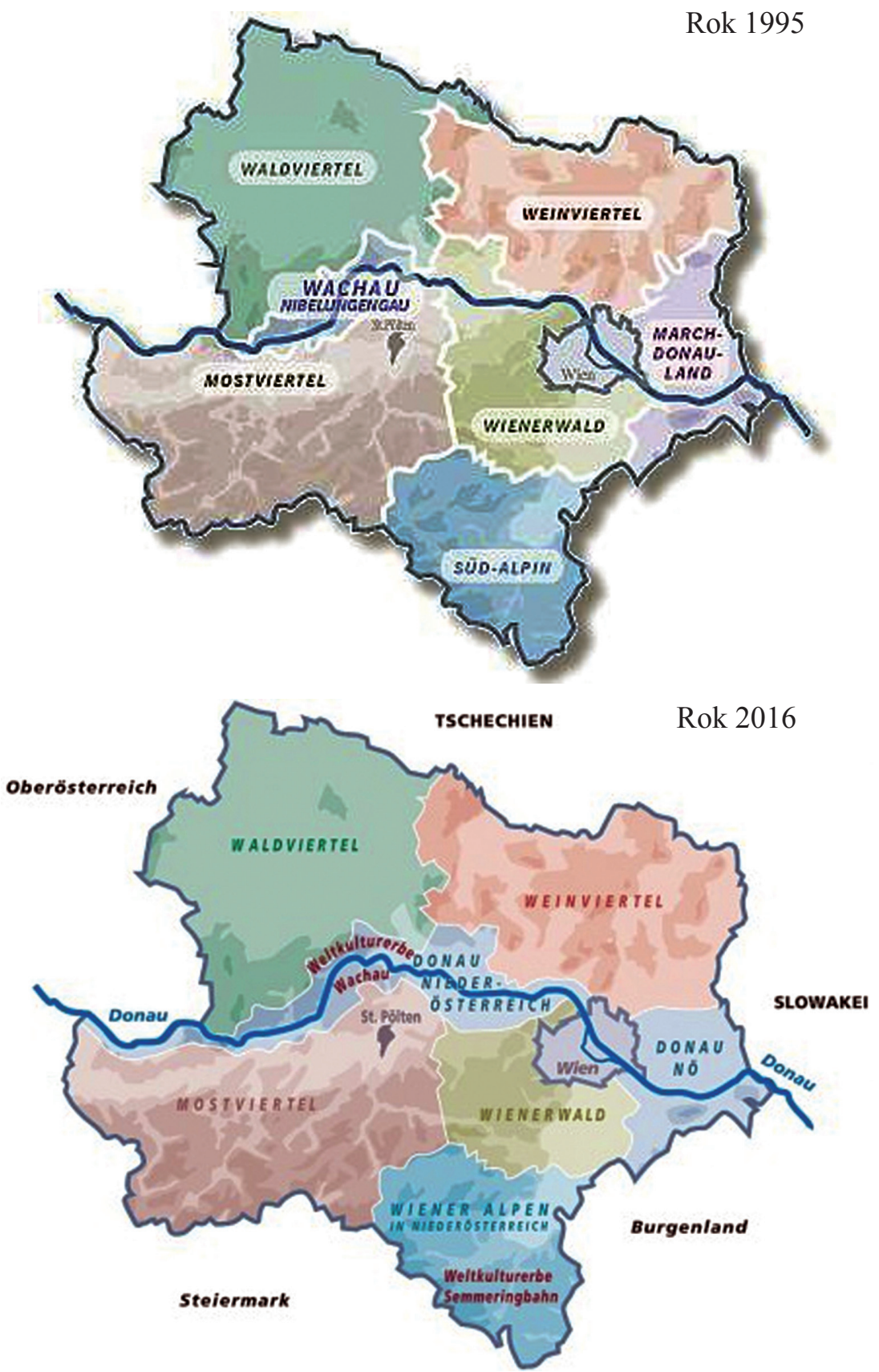

Ryc. 2. Podział Dolnej Austrii na regiony turystyczne z roku 1995 i 2016 Źródło: www.wandertipp.at oraz www.tourist-net.co.at/nidoe1.htm

Fig. 2. Division of Lower Austria into tourist regions from the years 1995 and 2016 Source: www.wandertipp.at and www.tourist-net.co.at/nidoel.htm 
Tab. 1. Analiza SWOT turystyki w Dolnej Austrii

Tab. 1. SWOT analysis of tourism in Lower Austria

\begin{tabular}{|c|c|}
\hline Mocne strony / Strong points & Słabe strony / Weak points \\
\hline $\begin{array}{l}\text { - bliskie położenie dużych metropolii } \\
\text { - bogata oferta kulturalna } \\
\text { - rzeka Dunaj i dziedzictwo kulturowe } \\
\text { Doliny Wachau } \\
\text { - wysokiej jakości oferta zdrowotna i lecznicza } \\
\text { - atrakcyjne naturalne tereny } \\
\text { - wysokiej jakości produkty regionalne }\end{array}$ & $\begin{array}{l}\text { - niska koncentracja oferty turystycznej } \\
\text { - za mało ofert skierowanych do określonych } \\
\text { grup klientów } \\
\text { - niska ponadregionalna świadomość } \\
\text { atrakcyjności turystycznej Dolnej Austrii - } \\
\text { stereotyp Austrii jako kraju alpejskiego } \\
\text { - brak konsekwencji we wdrażaniu projektów }\end{array}$ \\
\hline Szanse / Chances & Zagrożenia / Threats \\
\hline $\begin{array}{l}\text { - wzrost demograficzny } \\
\text { - trend do regionalizacji ofert turystycznych } \\
\text { - wzrost świadomości zdrowotnej } \\
\text { społeczeństwa } \\
\text { - poszukiwanie i pozyskiwanie nowych } \\
\text { rynków turystycznych }\end{array}$ & $\begin{array}{l}\text { - niestabilna sytuacja finansowa } \\
\text { - cenowa konkurencja (noclegów) dużych } \\
\text { ośrodków miejskich }\end{array}$ \\
\hline
\end{tabular}

Źródło: Tourismusstrategie Niederösterreich 2020

Source: Tourismusstrategie Niederösterreich 2020

W strategii przedstawiono wizję, według której Dolna Austria ma rozwijać się jako kraj radości życia i kultury, wytyczone dla niej zostały główne cele oraz określone produkty turystyczne tzw. filary. Do głównych celów zaliczono wzmocnienie Dolnej Austrii jako konkurencyjnego regionu turystycznego, poprzez wzrost liczby noclegów, czyli skierowanie oferty na rynek zachodni i rynek Europy Środkowo-Wschodniej. Wiąże się to z rozbudową ofert standardowych i ofert skierowanych do określonych grup klientów, np. do rodzin, dzieci i młodzieży, osób starszych, klientów, którzy preferują wyjazdy profilaktyczno-zdrowotne itp. Następstwem tego mają być działania inwestycyjne, mające na celu rozbudowę bazy turystycznej oraz urządzeń specjalistycznych. Kolejny cel to dążenie do optymalnego wzrostu wartości rynkowej, a nie tylko krótkotrwałych maksymalizacji dochodów. Wiąże się to z pozyskiwaniem nowych partnerów, współpracą między lokalnymi i regionalnymi organizacjami zajmującymi się turystyką oraz tworzeniem tzw. programów lojalnościowych. Dolna Austria planuje także kierować swoją ofertę do turystów indywidualnych oraz do osób spędzających tu krótki urlop. Rozpowszechnienie turystyki indywidualnej, jak również efektywniejsze zorganizowanie turystyki masowej, ma odciążyć najbardziej popularne miejscowości turystyczne, m.in. poprzez promocję nowych produktów turystycznych. Wszelkiego rodzaju działania mają również na celu przedłużenie ofert 
turystycznych na sezony wiosenny i jesienny oraz tam, gdzie to możliwe, również zimowy.

W strategii określono także cztery filary Dolnej Austrii - przyrodnicze i kulturowe, które mają stać się przyszłością turystyki. Zaliczono do nich: krajobraz, przyrodę i góry; ofertę zdrowotną i leczniczą; lokalną kuchnię, wino i regionalne produkty oraz promocję sztuki, kultury i związanej z nią historii.

Działaniem sprzyjającym rozwojowi turystyki w Dolnej Austrii jest wprowadzenie jednorazowo płatnej, sezonowej karty (Niederösterreich Card), która upoważnia do wielu zniżek w obiektach turystycznych i wolnego wstępu do kilkuset miejsc - atrakcji turystycznych. Ponadto całą Austrię charakteryzuje sieć drogowa o najwyższym poziomie, a nowoczesna sieć kolejowa pozwala na dotarcie do prawie każdego ważniejszego ośrodka turystycznego. Takie dogodne połączenia sprawiają, że wielu mieszkańców dużych aglomeracji miejskich przenosi się do mniejszych miejscowości leżących w ich pobliżu. Zjawisko to może być korzystną tendencją w promocji regionów turystycznych.

\section{TURYSTYKA W EGGENBURGU}

Jednym z sześciu regionów turystycznych Dolnej Austrii jest Waldviertel, w obrębie którego w powiecie Horn i przy granicy regionu Weinviertel leży miejscowość Eggenburg. Zgodnie z założeniami głównymi zadaniami regionu Waldviertel są: osiągnięcie pozycji wiodącego regionu zdrowotnego w Europie, rozwinięcie oferty turystycznej bazującej na zasobach środowiska przyrodniczego i regionalnych produktach (lokalnej kuchni oraz rzemiośle), a także na ofercie turystyki kulturowej. Duży nacisk kładzie się na możliwość realizacji aktywnego wypoczynku, uprawiania różnych dyscyplin sportowych. Ważnym elementem rozwoju turystyki jest otwartość i gościnność ludności miejscowej.

Eggenburg to niewielka miejscowość, jej powierzchnia wynosi 2,355 ha, a w roku 2016 zamieszkiwało ją 3569 osób (www.statistik.at/web_de/statistiken/ index.html).

Na terenie miasta są ślady osadnictwa z czasów neolitu. W roku 1173 powstał plan założeń miasta, na którym wyraźnie wyodrębniono rynek. 13 sierpnia 1277 Eggenburg otrzymał prawa miejskie. W XIII wieku miasto ogrodzono murami obronnymi, które stały się jego głównym produktem turystycznym (www.eggenburg.at). Eggenburg położony ok. $70 \mathrm{~km}$ od Wiednia uzyskał połączenie kolejowe ze stolicą w roku 1887. 


\section{BAZA MATERIALNA I RUCH TURYSTYCZNY}

W kontekście istniejącej infrastruktury turystycznej oraz ruchu turystycznego trudno doszukiwać się masowej turystyki w Eggenburgu. Miasto dysponuje łącznie 154 miejscami noclegowymi (ryc. 3) w hotelach, kwaterach prywatnych oraz w schronisku młodzieżowym. Oprócz tego wydzielony jest, wyposażony w infrastrukturę, plac kamperowy.

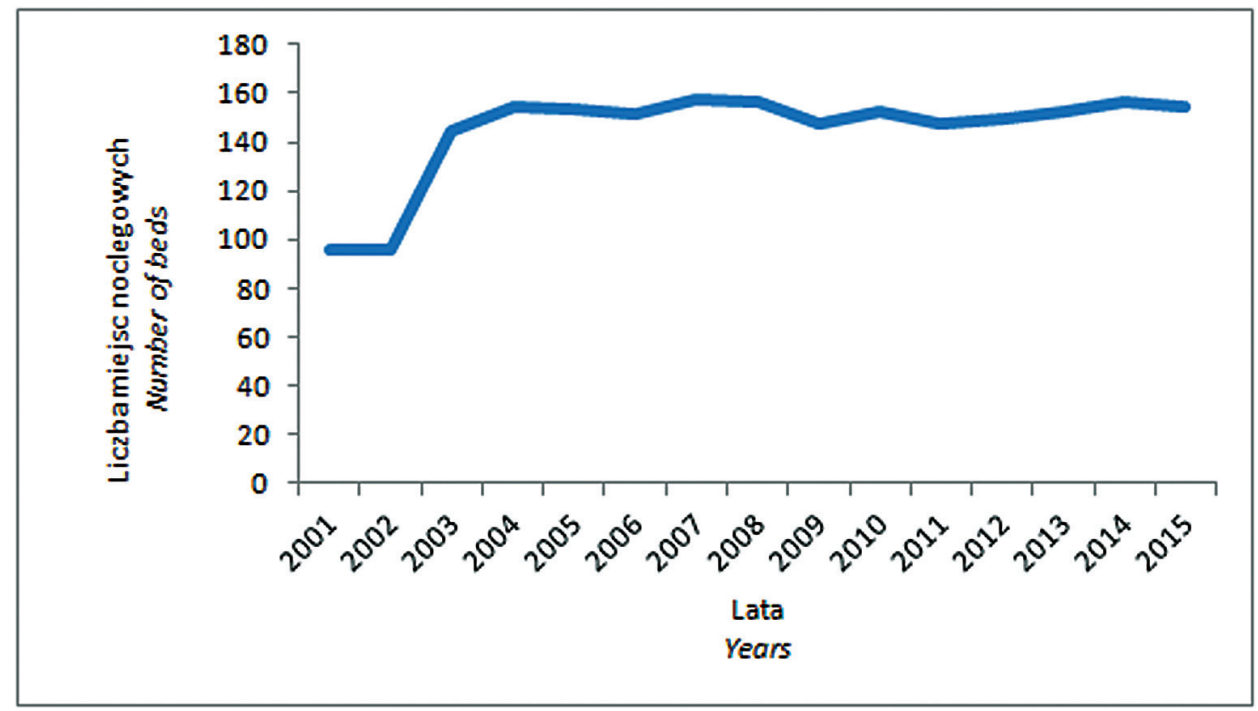

Ryc. 3. Liczba miejsc noclegowych Eggenburga w latach 2001-2015

Źródło: Opracowanie własne na podstawie Tourismusinformation Eggenburg

Fig. 3. Number of accomodation places in Eggenburg in the years 2001-2015

Source: Own elaboration based on Tourismusinformation Eggenburg

Od kilkunastu lat liczba miejsc noclegowych w Eggenburgu utrzymuje się na podobnym poziomie.

Biorąc z kolei pod uwagę liczbę udzielonych noclegów, można zaobserwować pewne wahania (ryc. 4). Największą ich liczbę odnotowano w roku 2005 (11 903), spadek nastąpił w roku 2014 (8859), ale od tego momentu obserwuje się już niewielką tendencję wzrostową.

W rozkładzie czasowym ruchu turystycznego (ryc. 5) można zaobserwować również pewne zmiany. Najwięcej przyjazdów odnotowano w roku 2005 (5432), natomiast w kolejnych latach nastąpił ich niewielki spadek. Od roku 2012 ruch turystyczny sukcesywnie wzrasta. W Eggenburgu turyści spędzają przeciętnie dwa dni. 


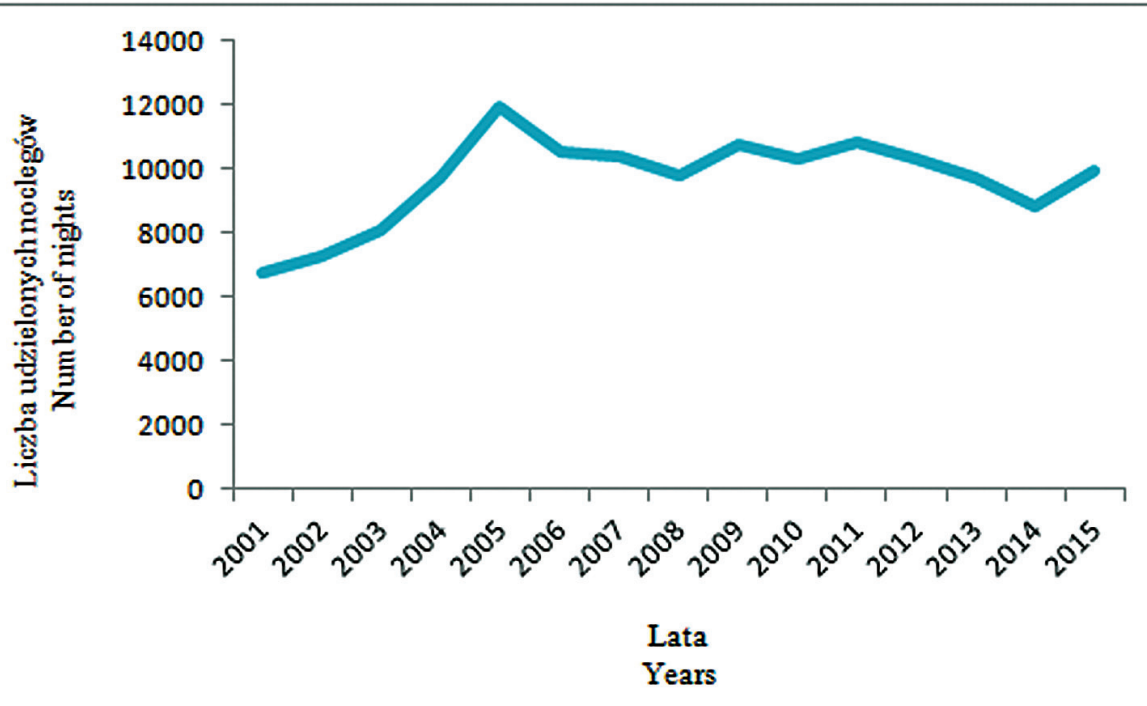

Ryc. 4. Liczba udzielonych noclegów w Eggenburgu, w latach 2001-2016

Źródło: Opracowanie własne na podstawie Tourismusinformation Eggenburg

Fig. 4. The number of overnight stays in Eggenburg, in the years 2001-2016

Source: Own elaboration based on Tourismusinformation Eggenburg

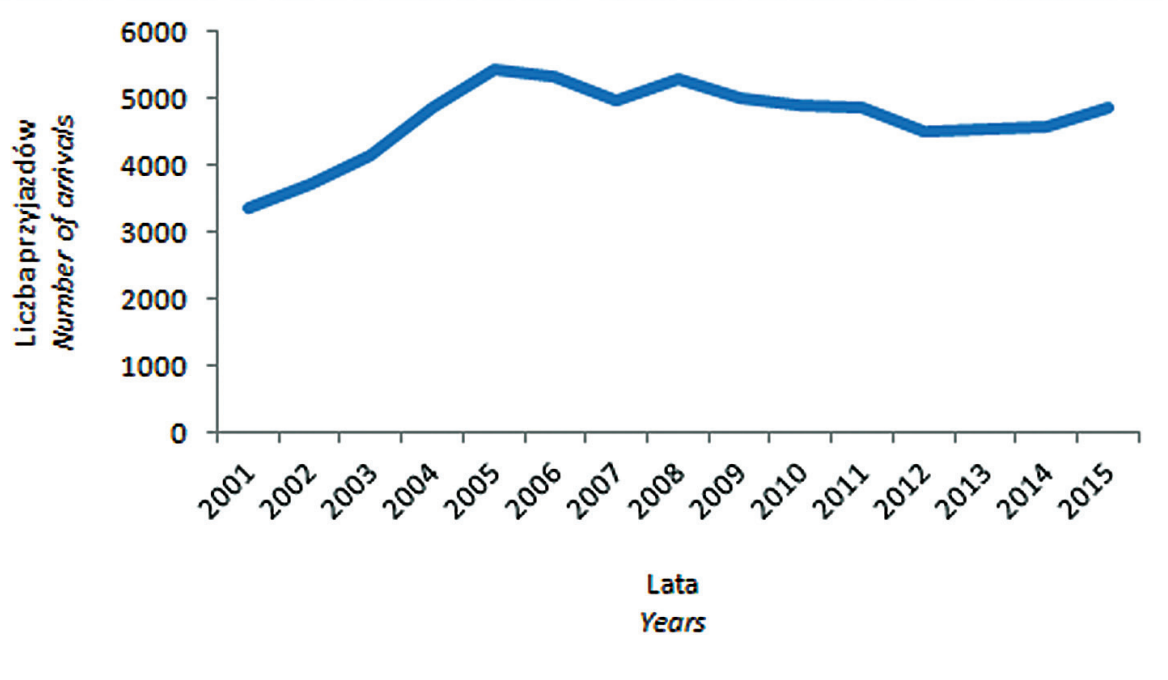

Ryc. 5. Liczba przyjazdów do Eggenburga w latach 2001-2016

Źródło: Opracowanie własne na podstawie Tourismusinformation Eggenburg

Fig. 5. The number of arrivals in Eggenburg in the years 2001-2016

Source: Own elaboration based on Tourismusinformation Eggenburg 
$\mathrm{Na}$ bazę gastronomiczną miasta składają się restauracje, kawiarnie, które dysponują w sumie ponad dwustoma miejscami (Tourismus Information Eggenburg). Uzupełnienie tej infrastruktury i ważną atrakcję przyciągającą turystów stanowią winiarnie i tzw. heurigi, które nie są uwzględniane w opracowaniach statystycznych.

Mimo niewielkiej pod względem liczebności podstawowej infrastruktury turystycznej Eggenburg jest przykładem miejscowości, która aspiruje do zdobycia pozycji na mapie atrakcyjności turystycznej regionu ze względu na walory kulturowe. W mieście znajdują się dwa kościoły: klasztor i kościół redemptorystów z wieku XVII oraz Kościół Parafialny św. Szczepana z XII wieku, w którym atrakcją turystyczną jest krypta czaszek. Oba kościoły znajdują się w granicach murów obronnych. Mury miasta zostały wzniesione na przełomie XII/XIII wieku, posiadały trzy bramy miejskie, które w wieku XIX zostały nieco zniszczone. Do dnia dzisiejszego, po renowacji, przetrwało 1,8 km murów obronnych, które udostępnione są do zwiedzania zarówno indywidualnie, jak i z przewodnikiem. Wokół murów obronnych poprowadzona jest pieszo-rowerowa ścieżka edukacyjna. I właśnie te mury są flagowym produktem miejscowości, co zresztą jest również podkreślone w logo Eggenburga (ryc. 6) oraz promującym haśle, które w wolnym tłumaczeniu brzmi jako „Eggenburg - w magii czasu” (org. Eggenburg im Zauber der Zeit).
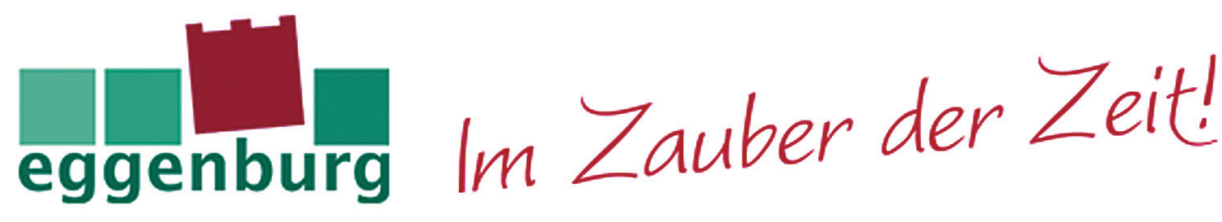

\footnotetext{
Ryc. 6. Logo Eggenburga

Źródło: www.eggenburg.at

Fig. 6. Logo of Eggenburg

Source: www.eggenburg.at
}

Mając świadomość, że mury (ryc.7) stanowią niewątpliwy atut miejscowości, organizowane są różnego rodzaju wydarzenia kulturalne, powiązane z nimi tematycznie. Do najbardziej znanych nie tylko w Austrii, ale również poza granicami kraju, zaliczany jest kilkudniowy festyn średniowieczny (org. Mittelalterfest), podczas którego miasto przeobraża się w średniowieczną osadę. Święto to organizowane jest jesienią, a więc poza typowym sezonem turystycznym. W organizację tego wydarzenia zaangażowani są mieszkańcy Eggenburga, którzy podczas festynu mają możliwość prezentowania i promowania swoich lokalnych wyrobów - produktów spożywczych i rękodzieła artystycznego oraz tradycyjnych 
przedmiotów codziennego użytku. Od niedawna ma w tym udział również, powstałe w 2016 roku, stowarzyszenie - Manufactura Eggenburg. Zrzesza ono rzemieślników, którzy organizują prezentacje i warsztaty z zakresu ręcznej produkcji różnych artykułów, oparte na tradycyjnych metodach. Kolejną atrakcją związaną z murami jest działające w okresie letnim kino „Pod księżycem” na świeżym powietrzu (org. Mondscheinkino).

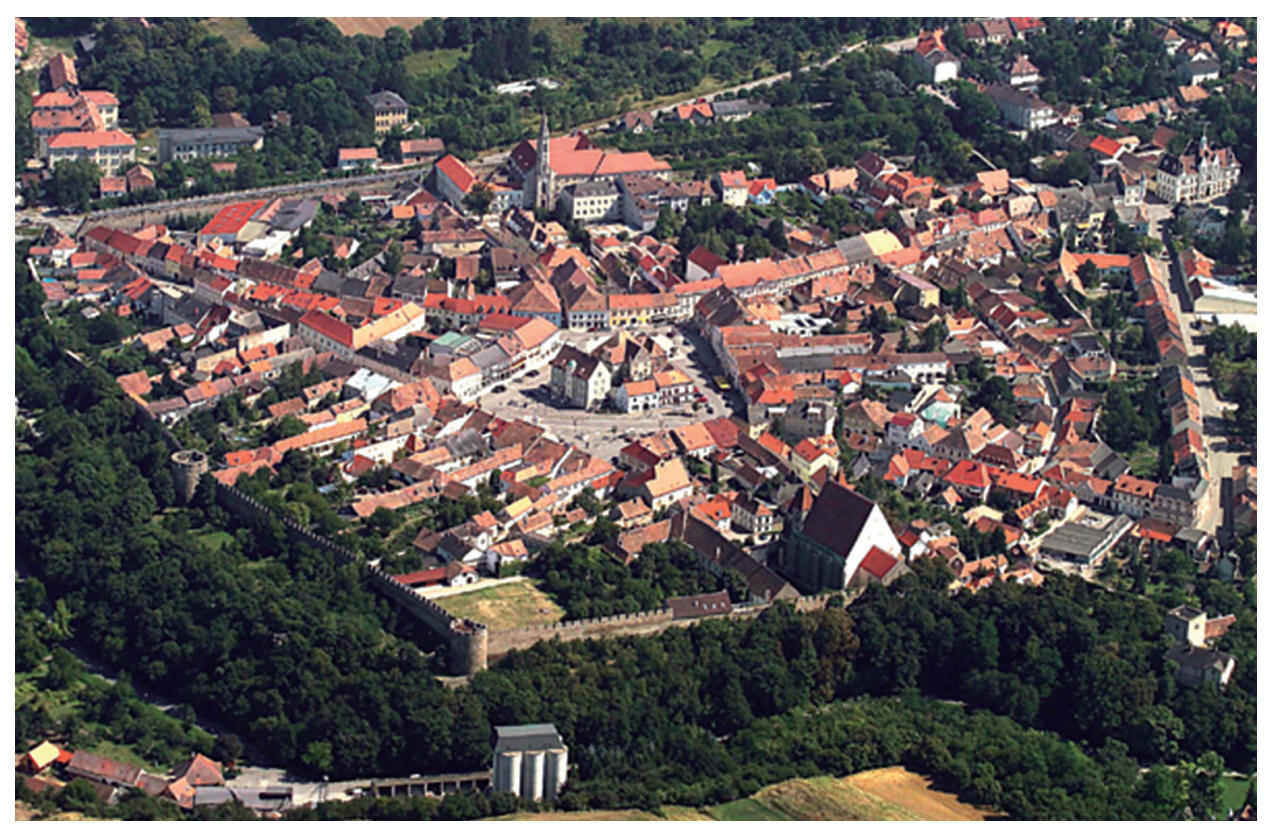

Ryc. 7. Eggenburg - widok na mury miasta

Źródło: www.eggenburg.gv.at/Stadtmauerstadt_Eggenburg

Fig. 7. Eggenburg - view of the city walls

Source: www.eggenburg.gv.at/Stadtmauerstadt_Eggenburg

Atrakcję turystyczną miasta stanowią również dwa muzea. Krahuletz-Muzem powstało w 1902 roku w neorenesansowym stylu, od 1994 roku posiada stałą ekspozycję geologiczną, organizowane są również wystawy czasowe. Drugie muzeum działa w połączeniu z kawiarnią i sklepem. Otwarte zostało w 2003 roku, a jego zadaniem jest nostalgiczne przypomnienie klimatu lat 50., 60. i 70. Zobaczyć w nim można sprzęty codziennego użytku minionego okresu oraz kolekcję starych samochodów. Organizowane są różne spotkania, warsztaty, zloty, np. motocyklistów. Wydarzenia organizowane przez to muzeum cieszą się dużą popularnością i są przykładem koncepcji ukierunkowywania oferty turystycznej do konkretnej grupy klientów. 
Rynek otoczony kamienicami i ratuszem z XIX wieku w niezmienionym kształcie przetrwał do dnia dzisiejszego. Atrakcją turystyczną jest elewacja budynku z XVI wieku, z wymalowaną sceną stworzenia świata ze Starego Testamentu.

W Eggenburgu odbywają się cyklicznie festyny (np. Jesień Win w Dolnej Austrii) i targi lokalnych wyrobów, a dużą popularnością wśród turystów i ludności miejscowej cieszą się winiarnie oraz heurigi. Heurigi, to lokale gastronomiczne zlokalizowane przy gospodarstwach, charakterystyczne dla wschodniej Austrii, w których serwuje się produkty spożywcze oraz wino, wyprodukowane $\mathrm{w}$ danym roku, najczęściej własnej produkcji (niem. heuriger - tegoroczny). Jest to zgodne ze strategią rozwoju Dolnej Austrii, której zadaniem jest również promocja lokalnej, zdrowej kuchni i regionalnych produktów.

W Eggenburgu istnieje również możliwość uprawiania sportu i aktywnego wypoczynku. W mieście znajduje się basen - czynny w sezonie letnim, lodowisko - działające zimą i hala sportowa. Największym atutem są jednak wytyczone w okolicy trasy spacerowe i rowerowe, które łączą wiele okolicznych atrakcji i miejscowości.

Władze miasta mające świadomość jego mocnych stron, ale równocześnie znające jego słabe punkty postanowiły otworzyć się na kolejną formę turysty$\mathrm{ki}$ - senioralną. Dla tej grupy klientów przygotowano trasy spacerowe, rowerowe, ścieżki do nordic-walking, oferuje się im również imprezy kulturalne, np. koncerty, organizuje warsztaty, zajęcia sportowe. W ostatnich latach powstało osiedle apartamentów, w których osoby starsze mogą wykupić sobie mieszkania, równocześnie mając gwarancję fachowej opieki lekarskiej sąsiadującego z osiedlem szpitala.

\section{PODSUMOWANIE}

W turystyce obecnie dominuje rynek nabywcy, zróżnicowane są potrzeby, motywacje i aktywność turystyczna. Wzrasta samodzielność turystów w wyborze programów i ich realizacji. Spada znaczenie pośredników, a usługi kupowane są bezpośrednio u producentów. Coraz częściej motywami podróży stają się zwykła ciekawość i aktywny wypoczynek w czystym ekologicznie środowisku, wzrasta również świadomość zdrowotna wypoczywających osób. Preferuje się turystykę zrównoważoną, chroniąc tym samym to, co najcenniejsze dla danego obszaru.

Chcąc właściwie zarządzać turystyką, należy postawić sobie pewne cele i zadania. Dolna Austria jest tego doskonałym przykładem, lata doświadczeń, obserwacji i analiz rynku turystycznego pozwoliły władzom tego landu wyodrębnić w jego obszarze sześć regionów turystycznych, z których każdy ma odmienny 
charakter i daje szanse rozwoju różnych form turystyki. Współpraca, spójna wizja rozwoju i przemyślana strategia zgodna z zasadami zrównoważonego rozwoju bazują właśnie na regionalizacji produktów turystycznych.

Wszystkie podejmowane działania są spójne z główną ideą, ale dają równocześnie szansę zachowania własnej tożsamości. Wiele obszarów mogłoby brać przykład, jak odpowiednio zarządzając turystyką i promując ją, wykorzystując indywidualny potencjał, można się konsekwentnie rozwijać.

Eggenburg może stać się znaczącą destynacją turystyczną, dlatego ważne jest poszukiwanie indywidualnych mocnych stron nawet najmniejszych miejscowości. Dzięki temu można rozwijać turystykę na bazie regionalnych, często unikatowych, produktów turystycznych.

Turystyka jest zjawiskiem tak dynamicznym, jak i złożonym. Małej jednostce trudno wybić się na tym rynku, dlatego, aby osiągnąć zamierzony efekt, należy się nawzajem wspierać, tworzyć programy lojalnościowe i wspólnie kreować produkty turystyczne danego regionu.

\section{LITERATURA}

Gmyrek K., 2004: Potencjat turystyczny Dolnej Austrii, Folia Turistica, 15, 103-123.

Gmyrek-Gołąb K., Łabaj M., 2005: Metodyka zrównoważonego zagospodarowania turystycznego gminy, [w:] Sporty zimowe, strategia rozwoju, badania naukowe, Wydawnictwo AWF Kraków, Kraków, 31-37.

Kowalczyk A., Derek M., 2010: Zagospodarowanie turystyczne, Wydawnictwo Naukowe PWN, Warszawa, 122-124.

Kruczek Z., Zmyślony P., 2010: Regiony turystyczne, Proksenia, Kraków, 7-12.

Liszewski S., 2003: Region turystyczny, [w:] Turyzm 13, z. 1, Wydawnictwo Uniwersytetu Łódzkiego, Łódź, 43-54.

Tourismusstrategie Niederösterreich 2020, Amt der NÖ Landesregierung.

\section{Netografia}

www.gastgeberkatalog.de/regionen/austria_regionen.en.htm (dostęp: 18.09.2016)

www.wandertipp.at (dostęp: 18.09.2016)

www.tourist-net.co.at/nidoe1.htm (dostęp: 18.09.2016)

www.eggenburg.at (dostęp: 25.09.2016)

www.eggenburg.gv.at/Stadtmauerstadt_Eggenburg (dostęp: 25.09.2016)

\section{SUMMARY}

Lower Austria is a federated state, internally very diverse in terms of tourist attraction and suitability for various forms of tourism. Through various activities, it strives to achieve success on the tourist market, changing the stereotype of tourist's Austria perception as a country of mountains and large cities. 
The aim of this study is to show that even small towns, for example Eggenburg, can in the future achieve success on the tourist market and create regional tourism products, when their development is based on cooperation, consistent vision of development and well-thought-out strategy.

The study is empirical, based on available statistical data, and it also includes information from development strategies. The analysis conducted in the study showed that small towns appropriately managing the tourism, promoting it on the basis of individual potential and identifying their products, can be competitive on the tourist market. 